on-line at: www.actabp.pl

Regular paper

This paper is dedicated to Professor Liuda Rasteikiene on the occasion of her 80th birthday

\title{
Reduction of nitroaromatic compounds by NAD(P)H:quinone oxidore- ductase (NQO1): the role of electron-accepting potency and structural parameters in the substrate specificity
}

\author{
Lina Misevičienè, Žilvinas Anusevičius, Jonas Šarlauskas and Narimantas Čènas ${ }^{\bowtie}$ \\ Institute of Biochemistry, Vilnius, Lithuania, ${ }^{\circledR}$-mail: ncenas@bchi.lt
}

Received: 01 March, 2006; revised: 14 April, 2006; accepted: 14 June, 2006

available on-line: 21 August, 2006

\begin{abstract}
We aimed to elucidate the role of electronic and structural parameters of nitroaromatic compounds in their two-electron reduction by NAD(P)H:quinone oxidoreductase (NQO1, DT-diaphorase, EC 1.6.99.2). The multiparameter regression analysis shows that the reactivity of nitroaromatic compounds $(n=38)$ increases with an increase in their single-electron reduction potential and the torsion angle between nitrogroup(s) and the aromatic ring. The binding efficiency of nitroaromatics in the active center of NQO1 exerted a less evident role in their reactivity. The reduction of nitroaromatics is characterized by more positive entropies of activation than the reduction of quinones. This points to a less efficient electronic coupling of nitroaromatics with the reduced isoalloxazine ring of $\mathrm{FAD}$, and may explain their lower reactivity as compared to quinones. Another important but poorly understood factor enhancing the reactivity of nitroaromatics is their ability to bind at the dicumarol/quinone binding site in the active center of NQO1.
\end{abstract}

Keywords: DT-diaphorase, nitroaromatic compounds, explosives, reduction mechanism, reduction potential

\section{INTRODUCTION}

Mammalian NAD(P)H:quinone reductase (NQO1, DT-diaphorase, EC 1.6.99.2) is a dimeric flavoenzyme containing one molecule of FAD per subunit. It catalyzes the two-electron reduction of quinones and nitroaromatic compounds. The activity of NQO1 is frequently elevated in various tumours (Ross et al., 2000). This provides an opportunity for designing quinoidal compounds, e.g., RH1 (2,5-diaziridinyl-3-(hydroxymethyl)-6-methyl-1,4-benzoquinone), whose antitumour activity stems from their reduction by NQO1 to alkylating aziridinylhydroquinone products (DiFrancesco et al., 2004, and references therein). Quinone reduction by NQO1 follows a 'ping-pong' scheme and often proceeds at a high maximal rate, $>1000 \mathrm{~s}^{-1}$ (Tedeschi et al., 1995). Dicumarol, cibacron blue, and flavones act as in- hibitors competitive to $\mathrm{NAD}(\mathrm{P}) \mathrm{H}$ (Chen et al., 1999; Bianchet et al., 2004, and references therein). Recent $\mathrm{X}$-ray and computer modeling studies of NQO1 provided evidence that mono- and bicyclic quinones, dicumarol, and the dihydronicotinamide ring of NADPH bind at the same domain in the vicinity of the isoalloxazine ring of FAD (Bianchet et al., 2004, and references therein). The reactivity of quinones increases with an increase in their single-electron reduction potential $\left(\mathrm{E}_{7}^{1}\right)$ and decreases with an increase in their Van der Waals volume above $200 \AA^{3}$, due to steric hindrance (Anusevičius et al., 2002).

Nitroaromatic compounds, although less reactive than quinones, comprise another important group of substrates for NQO1. The two-electron (hydride) reduction of nitroaromatics leads to the formation of nitroso compounds, which are further spontaneously reduced to DNA-alkylating hydroxyl-

Abbreviations: ANTA, 5-nitro-1,2,4-triazol-3-amine; CB-1954, 5-(aziridin-1-yl)-2,4-dinitrobenzamide; CL-14, 5,7-diamino4,6-dinitrobenzofuroxan; DNBF, 4,6-dinitrobenzofuroxan; $\mathrm{E}_{7}^{1}$, single-electron reduction potential; $k_{\text {cat }}$ catalytic constant; $k_{\text {cat }} / K_{\mathrm{m}^{\prime}}$ bimolecular rate constant; NQO1, NAD(P)H:quinone oxidoreductase; NTO, 5-nitro-1,2,4-triazol-3-one; TNC, 1,3,6,8-tetranitrocarbazole; TNT, 2,4,6-trinitrotoluene; VdWvol, Van der Waals volume. 
amines (Knox \& Chen, 2004; Arlt et al., 2005, Race et al., 2005, and references therein). NQO1 plays a considerable role in mammalian cell cytotoxicity and genetoxicity of nitroaromatic pollutants - components of exhaust gases or residues of explosives in the environment (Čènas et al., 2001; Arlt et al., 2005, and references therein). Besides, the antitumour activity of 5-(aziridin-1-yl)-2,4-dinitrobenzamide (CB1954) and its analogues is supposed to stem from their reductive activation by NQO1 (Knox \& Chen, 2004, and references therein). However, because of the insufficient kinetic studies, the mechanism and substrate specificity of nitroreductase reactions of NQO1 are still poorly understood. In particular, it is unclear how the enzyme reactivity is influenced by the electron-accepting potency of nitroaromatics and the efficiency of their interaction with the active center, i.e., the structural parameters (Šarlauskas et al., 1997; Knox \& Chen, 2004, and references therein). There is no X-ray data on the complexes of nitroaromatic compounds in the active center of NQO1, except for several computer modeling studies (Chen et al., 1999; Skelly et al., 1999; Arlt et al., 2005).

Continuing our previous studies (Šarlauskas et al., 1997; 2004a; 2004b; Miškinienè et al., 1999; Čènas et al., 2001; Nemeikaitè-Čènienè et al., 2004; 2004a, 2004b), in this work we attempted to distinguish between the effects of the electron-accepting potency and the structural parameters of nitroaromatics in their reduction by NQO1. For this purpose, we used a series of structurally diverse nitroaromatic compounds with a broad range of reduction potentials, including the antitumour agents nitracrine, CB-1954 and its analogues, and the nitroaromatic explosives 2,4,6-trinitrotoluene (TNT), tetryl, pentryl, 1,3,6,8-tetranitrocarbazole (TNC), 5-nitro-1,2,4-triazol3-one (NTO), 5-nitro-1,2,4-triazol-3-amine (ANTA), 4,6-dinitrobenzofuroxan (DNBF), and 5,7-diamino4,6-dinitrobenzofuroxan (CL-14) (Fig. 1).

\section{MATERIALS AND METHODS}

Rat liver NQO1 was purified as described (Prochaska, 1988). Enzyme concentration was determined spectrophotometrically, using $\Delta \varepsilon_{460}=11$ $\mathrm{mM}^{-1} \mathrm{~cm}^{-1}$. Model nitroaromatic compounds (nitrobenzene, $p$-nitrobenzyl alcohol, $p$-nitrobenzoic acid, $p$-nitroacetophenone, 3,5-dinitrobenzoic acid, 3,5-dinitrobenzamide, $p$-nitrobenzaldehyde, nifuroxime, nitrofurantoin, and $o-, m_{-}$, and $p$-dinitrobenzenenes), NADPH, dicumarol, cytochrome $c$, 2-methyl-1,4-naphthoquinone, and 2-methyl-3-hydroxy1,4-naphthoquinone were obtained from Sigma and used without further purificiation. Nitracrine (Fig. 1) was a generous gift of Dr. Igor Degterev (Institute of Chemical Physics, Moscow, Russia). The methods of synthesis of other nitroaromatic compounds (Fig. 1) were given in our previous papers: TNT and its amino- and hydroxylamino derivatives (Šarlauskas et al., 2004a), tetryl, pentryl, and TNC (Čènas et al., 2001), CB-1954 and its derivatives (Miškinienè et al., 1999), nitrobenzimidazoles and nitrobenzimidazolones (Šarlauskas et al., 1997), NTO and ANTA (Šarlauskas et al., 2004b), DNBF (Nemeikaitè-Čènienè et al., 2004). CL-14 was synthesized according to Mehilal et al. (2003). Dipentryl was synthesized according to Agrawal et al. (2000). The purity of compounds was determined using melting points, TLC, NMR, IR, and elemental analysis.

All the kinetic measurements were carried out in $0.1 \mathrm{M} \mathrm{K}$-phosphate ( $\mathrm{pH} 7.0)$, containing $1 \mathrm{mM}$ EDTA at $25^{\circ} \mathrm{C}$, using a Hitachi-557 spectrophotometer. Tween $20(0.01 \%)$, and bovine serum albumin $(0.25 \mathrm{mg} / \mathrm{ml})$ were added as NQO1 activators, unless specified otherwise. In most cases, the reaction rates were determined by following the decrease in the absorbance of NADPH in the presence of aromatic nitrocompounds $\left(\Delta \varepsilon_{340}=6.2 \mathrm{mM}^{-1} \mathrm{~cm}^{-1}\right)$. The reaction rates were corrected for an intrinsic NADPH oxidase activity of NQO1, $0.03 \mathrm{~s}^{-1}$, and, where necessary, for the absorbance changes of nitroaromatic compounds at $340 \mathrm{~nm}$ (Šarlauskas et al., 1997; Nivinskas et al., 2001). The reduction of 4,5,6,7-tetranitrobenzimida-<smiles>[R]C(=O)c1cc(N2CC2)c([N+](=O)[O-])cc1[N+](=O)[O-]</smiles>

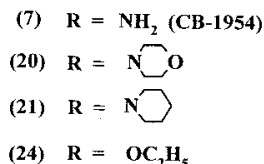<smiles></smiles><smiles>[Y]c1c([N+](=O)[O-])c([Z])c2[nH]c(=O)n([Tl])c2c1[Y]</smiles>

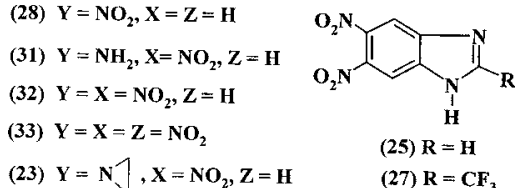<smiles>O=[N+]=Cn1c([N+](=O)[O-])n[nH]c1=O</smiles><smiles>Nc1nc([N+](=O)[O-])n[nH]1</smiles>
(19) ANTA<smiles>O=[N+]([O-])c1cc([N+](=O)[O-])c2[nH]c3c([N+](=O)[O-])cc([N+](=O)[O-])cc3c2c1</smiles>
(38) TNC<smiles></smiles>

(29) DNBF<smiles>[R]c1cc([N+](=O)[O-])cc([N+](=O)[O-])c1N(C)[N+](=O)[O-]</smiles>

(35) $\mathrm{R}=\mathrm{H}$

(36) $\mathrm{R}=\mathrm{NO}_{2}$ (Tetryl)

Figure 1. Structural formulae of nitroaromatic compounds studied in this work. 
zolone (compound 33, Fig. 1) was monitored according to $\Delta \varepsilon_{500}=2.6 \mathrm{mM}^{-1} \mathrm{~cm}^{-1}$ (Šarlauskas et al., 1997). The direct (nonenzymatic) oxidation of NADPH by nitroaromatic compounds in all the cases was below $1 \%$ of the enzymatic reaction rate. The catalytic constant $\left(k_{\text {cat }}\right)$ and the bimolecular constant of reduction of nitrocompound $\left(k_{\mathrm{cat}} / K_{\mathrm{m}}\right)$ correspond to the reciprocal intercepts and slopes of plots $[\mathrm{E}] / \mathrm{v}$ vs. $1 /\left[\mathrm{ArNO}_{2}\right]$, where $[\mathrm{E}]$ is enzyme concentration, and $\left[\mathrm{ArNO}_{2}\right]$ is the concentration of the nitrocompound. $k_{\text {cat }}$ is the number of NADPH molecules oxidized by a single active center of the enzyme per second. The kinetic constants were calculated by fitting to the standard hyperbolic expression. The competitive inhibition constants $\left(K_{\mathrm{i}}\right)$ of nitroaromatics were determined by monitoring the inhibition of NQO1-catalyzed 2-methyl-1,4-naphthoquinone-mediated reduction of added cytochrome $c\left(\Delta \varepsilon_{550}=20 \mathrm{mM}^{-1} \mathrm{~cm}^{-1}\right)$ in the presence of varied concentrations of NADPH (20-100 $\mu \mathrm{M}), 10 \mu \mathrm{M}$ 2-methyl-1,4-naphthoquinone, and $50 \mu \mathrm{M}$ cytochrome $c$. Typically, three or four concentrations of nitroaromatic compounds were used. The inhibition constants were calculated from the Cleland plots, plotting the dependence of reciprocal $k_{\text {cat }} / K_{\mathrm{m}}$ of NADPH on the inhibitor concentration. The inhibition of nitroreductase reactions of NQO1 by dicumarol was studied at a fixed concentration of NADPH, $200 \mu \mathrm{M}$, and varied concentrations of nitroaromatic compounds. The enthalpies $\left(\Delta \mathrm{H}^{\neq}\right)$and entropies $\left(\Delta \mathrm{S}^{\neq}\right)$of activation of reduction of nitroaromatic compounds were calculated from Eyring plots of $\log \left(k_{\text {cat }} / K_{\mathrm{m}}\right) / \mathrm{T}$ vs. $1 / \mathrm{T}$ using the data at seven fixed temperatures between 15 and $45^{\circ} \mathrm{C}$.

The quantum mechanical calculations of the Van der Waals volumes (VdWvol) of nitroaromatic compounds and the torsion angles between the nitrogroups and aromatic rings were performed using PC Spartan '04 (version 1.0.0) software (Wavefunction, Inc.). The structure was refined using a molecular mechanics force field method, with further full geometry optimization employing the AM1 Hamiltonian method. Multiparameter regression and statisti- cal analysis were performed using Statistica (version 4.3) software (Statsoft Inc., 1993).

\section{RESULTS}

The reduction rate constants of nitroaromatic compounds obtained partly in the present work and partly taken from our previous studies (Šarlauskas et al., 1997; Miškinienė et al., 1999; Čènas et al., 2001; Nemeikaitė-Čènienė et al., 2004; 2004a, 2004b), are given in Table 1. First, we analyzed the relationship between the reactivity of nitroaromatics and their electron-accepting potency. It is important to note that the potential of two-electron (hydride) reduction of nitroaromatic compounds cannot be measured in aqueous media. The products of two-electron reduction, nitroso compounds, are much stronger electron acceptors than the parent nitroaromatics, the reduction of nitroso compounds into the corresponding hydroxylamines being $10^{4}$ times faster than the reduction of nitroaromatics into the nitroso compounds (Race et al., 2005). The electrochemical reduction of nitroaromatics proceeds irreversibly, with a transfer of four or more electrons in the first step (Zuman et al., 1992). However, our previous studies on twoelectron reduction of nitroaromatics by Enterobacter cloacae nitroreductase have shown that there exists a parallelism between the electron- and hydride-accepting potency of nitroaromatics obtained by means of quantum-mechanical calculations (Nivinskas et al., 2001), as well as with their single-electron reduction potentials $\left(\mathrm{E}_{7}^{1}\right)$, measured by means of pulse-radiolysis (Wardman, 1989; Riefler \& Smets, 2000). An analogous parallelism exists between the single-electron reduction potentials of quinones and their calculated hydride-reduction potentials (Anusevičius et al., 2002; Čènas et al., 2004). In general, the $\log k_{\mathrm{cat}} / K_{\mathrm{m}}$ of nitroaromatic compounds tends to increase with an increase in their $\mathrm{E}_{7}^{1}$ (Fig. 2A). However, the relationship is poorly expressed $\left(r^{2}=0.622\right)$. The same trend is characteristic of $\log k_{\text {cat }}$ of nitroaromatics $\left(r^{2}\right.$
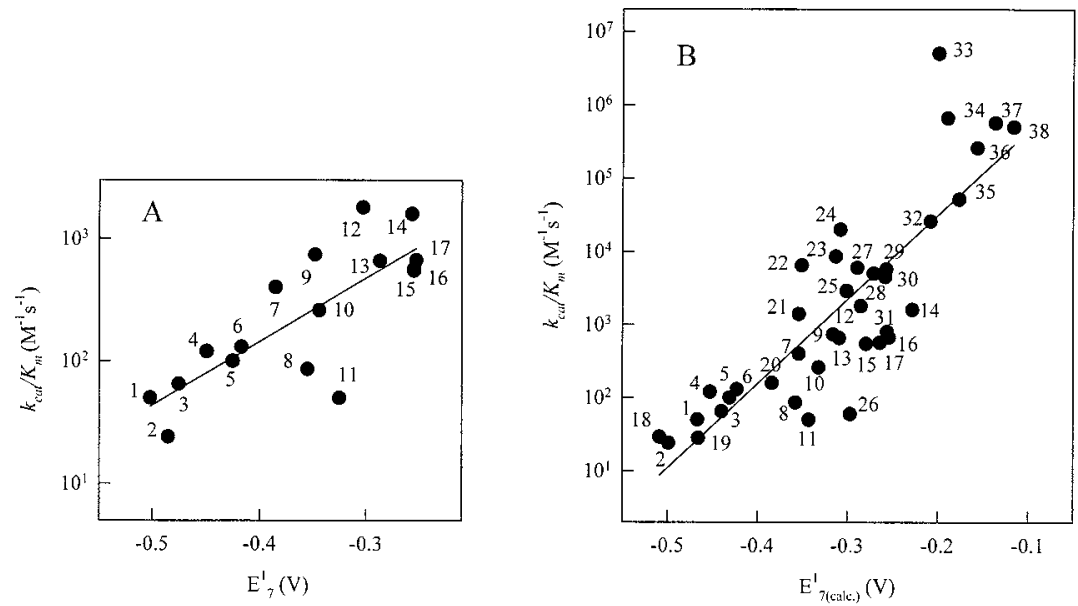

Figure 2. Dependence of the reactivity of NQO1 on the singleelectron reduction potential of nitroaromatic compounds.

A. Dependence of $\log k_{\mathrm{cat}} / K_{\mathrm{m}}$ of nitroaromatics on their $\mathrm{E}_{7}^{1}$. B. Dependence of $\log k_{\text {cat }} / K_{\mathrm{m}}$ of nitroaromatics on their $E_{7 \text { (calc.) }}^{1}$ The numbering of compounds is taken from Table 1. 
Table 1. Reduction rate constants of nitroaromatic compounds by NQO1 $\left(k_{\mathrm{cat}} / K_{\mathrm{m}}\right.$ and $\left.k_{\mathrm{cat}}\right)$, their competitive inhibition constants in NADPH:quinone reductase reaction $\left(K_{\mathrm{i}}\right)$, single-electron reduction potentials $\left(\mathrm{E}_{7}^{1}\right)$, Van der Waals volumes (VdWvol), and torsion angles of nitrogroups.

The values of $\mathrm{E}_{7}^{1}$ are taken from Wardman (1989) or from Riefler and Smets (2000) (compounds 1, 4, 6, 17). The $\mathrm{E}_{7(\mathrm{calc})}^{1}$ values are given in parentheses. The positions of nitrogroups with the corresponding torsion angle are given in parentheses. In all other cases, the torsion angle is zero.

\begin{tabular}{|c|c|c|c|c|c|}
\hline No. Compound & $k_{\mathrm{cat}} / K_{\mathrm{m}}\left(\mathrm{M}^{-1} \mathrm{~s}^{-1}\right)\left(\mathrm{k}_{\mathrm{cat}}\left(\mathrm{s}^{-1}\right)\right)^{\mathrm{a}}$ & $K_{\mathrm{i}}(\mu \mathrm{M})^{\mathrm{a}}$ & $\mathrm{E}_{7}^{1}(\mathrm{~V})$ & $\begin{array}{l}\text { VdWvol } \\
\left(\AA^{3}\right)\end{array}$ & Torsion angle $\left({ }^{0}\right)$ \\
\hline \multicolumn{6}{|c|}{ Compounds with available directly measured $E_{7}^{1}$ values: } \\
\hline 1. 2,4-Diamino-6-nitrotoluene & $5.0 \times 10^{1}(0.04)^{\mathrm{b}}$ & & $-0.502(-0.467)$ & 159 & \\
\hline 2. Nitrobenzene & $2.4 \times 10^{1}(0.06)^{\mathrm{c}}$ & 900 & $-0.485(-0.499)$ & 123 & \\
\hline 3. 4-Nitrobenzyl alcohol & $6.5 \times 10^{1}(0.12)^{\mathrm{c}}$ & & $-0.475(-0.440)$ & 147 & \\
\hline 4. 4-Amino-2,6-dinitrotoluene & $1.2 \times 10^{2}(0.04)^{\mathrm{b}}$ & & $-0.449(-0.453)$ & 171 & $28.9(2)$ \\
\hline 5. 4-Nitrobenzoic acid & $1.0 \times 10^{2}(0.05)^{\mathrm{c}}$ & & $-0.425(-0.431)$ & 149 & \\
\hline 6. 2-Amino-4,6-dinitrotoluene & $1.3 \times 10^{2}(0.04)^{\mathrm{b}}$ & & $-0.417(-0.423)$ & 171 & $38.6(4)$ \\
\hline $\begin{array}{l}\text { 7. 5-(Aziridin-1-yl)-2,4-dinitro- } \\
\text { benzoic acid amide (CB-1954) }\end{array}$ & $4.0 \times 10^{2}(0.05)^{\mathrm{d}}$ & 90 & $-0.385(-0.354)$ & 217 & $40.2(4), 19.8(2)$ \\
\hline 8. 4-Nitroacetophenone & $8.6 \times 10^{1}(0.06)^{\mathrm{c}}$ & & $-0.355(-0.358)$ & 160 & \\
\hline 9. 1,3-Dinitrobenzene & $7.4 \times 10^{2}(0.33)^{c}$ & & $-0.348(-0.316)$ & 142 & \\
\hline 10. 3,5-Dinitrobenzoic acid & $2.6 \times 10^{2}(0.03)$ & 100 & $-0.344(-0.332)$ & 171 & \\
\hline 11. 4-Nitrobenzaldehyde & $5.0 \times 10^{1}(0.10)^{c}$ & & $-0.325(-0.343)$ & 142 & \\
\hline 12. Nitracrine & $1.8 \times 10^{3}(0.11)$ & 40 & $-0.303(-0.285)$ & 334 & 57.7 \\
\hline 13. 1,2-Dinitrobenzene & $6.6 \times 10^{2}(0.14)^{c}$ & & $-0.287(-0.309)$ & 142 & 38.6 \\
\hline 14. 1,4-Dinitrobenzene & $1.6 \times 10^{3}(1.50)^{c}$ & 200 & $-0.257(-0.228)$ & 142 & \\
\hline 15. Nifuroxime & $5.5 \times 10^{2}(0.22)$ & 1000 & $-0.255(-0.279)$ & 133 & \\
\hline 16. Nitrofurantoin & $5.7 \times 10^{2}(0.16)$ & 120 & $-0.255(-0.264)$ & 202 & \\
\hline 17. 2,4,6-Trinitrotoluene (TNT) & $6.7 \times 10^{2}(1.00)^{\mathrm{c}}$ & 80 & $-0.253(-0.254)$ & 181 & $27.0(2,6)$ \\
\hline \multicolumn{6}{|l|}{ Compounds with calculated $E_{7}^{1}$ values: } \\
\hline 18. 3-Nitro-1,2,4-triazolone (NTO) & $2.9 \times 10^{1}(0.09)^{\mathrm{e}}$ & & $(-0.509)$ & 97 & 12.5 \\
\hline $\begin{array}{l}\text { 19. 5-Amino-3-nitro-1,2,4-triazole } \\
\text { (ANTA) }\end{array}$ & $2.8 \times 10^{1}(0.09)^{\mathrm{e}}$ & 200 & $(-0.466)$ & 100 & \\
\hline $\begin{array}{l}\text { 20. 5-(Aziridin-1-yl)-2,4-dinitro- } \\
\text { benzoic acid } N \text {-morpholide }\end{array}$ & $1.6 \times 10^{2}(0.05)$ & 60 & $(-0.384)$ & 289 & $18.5(2), 41.3(4)$ \\
\hline $\begin{array}{l}\text { 21. 5-(Aziridin-1-yl)-2,4-dinitro- } \\
\text { benzoic acid N-piperidide }\end{array}$ & $1.4 \times 10^{3}(0.67)^{\mathrm{d}}$ & 90 & $(-0.354)$ & 298 & $18.7(2), 39.1(4)$ \\
\hline $\begin{array}{l}\text { 22. 2-Hydroxylamino-4,6-dinitro- } \\
\text { toluene }\end{array}$ & $6.5 \times 10^{3}(0.35)^{\mathrm{b}}$ & & $(-0.351)$ & 180 & $36.8(6)$ \\
\hline $\begin{array}{l}\text { 23. 5-(Aziridin-1-yl)-4,6-dinitro- } \\
\text { benzimidazolone }\end{array}$ & $8.6 \times 10^{3}(1.50)^{\mathrm{f}}$ & $150^{\mathrm{f}}$ & $(-0.313)$ & 219 & 28.5 \\
\hline $\begin{array}{l}\text { 24. 5-(Aziridin-1-yl)-2,4-dinitro- } \\
\text { benzoic acid ethyl ester }\end{array}$ & $2.0 \times 10^{4}(5.00)^{\mathrm{d}}$ & 50 & $(-0.308)$ & 252 & $20.6(2), 39.0(4)$ \\
\hline 25. 5,6-Dinitrobenzimidazole & $2.9 \times 10^{3}(0.12)^{\mathrm{f}}$ & $125^{\mathrm{f}}$ & $(-0.301)$ & 170 & 38.0 \\
\hline 26. 3,5-Dinitrobenzamide & $6.0 \times 10^{1}(0.12)$ & 350 & $(-0.297)$ & 173 & \\
\hline $\begin{array}{l}\text { 27. 2-Trifluoromethyl-5,6-dinitro- } \\
\text { benzimidazole }\end{array}$ & $6.0 \times 10^{3}(0.12)^{\mathrm{f}}$ & & $(-0.289)$ & 203 & 38.0 \\
\hline 28. 5,6-Dinitrobenzimidazolone & $5.0 \times 10^{3}(0.70)^{\mathrm{f}}$ & $30^{f}$ & $(-0.271)$ & 176 & 37.0 \\
\hline 29. 4,6-Dinitrobenzofuroxane (DNBF) & $4.5 \times 10^{3}(0.50)^{g}$ & & $(-0.258)$ & 167 & $9.0(6)$ \\
\hline $\begin{array}{l}\text { 30. 5,7-Diamino-4,6-dinitrobenzo- } \\
\text { furoxane (CL-14) }\end{array}$ & $5.7 \times 10^{3}(0.62)$ & & $(-0.257)$ & 186 & $23.9(4), 31.1(6)$ \\
\hline $\begin{array}{l}\text { 31. 5-Amino-4,6-dinitrobenzimi- } \\
\text { dazolone }\end{array}$ & $8.0 \times 10^{2}(1.10)^{\mathrm{f}}$ & & $(-0.256)$ & 186 & $20(4), 13(6)$ \\
\hline 32. 4,5,6-Trinitrobenzimidazolone & $2.6 \times 10^{4}(2.40)^{\mathrm{f}}$ & $17^{\mathrm{f}}$ & $(-0.208)$ & 198 & $\begin{array}{l}31.4(4), 53.7(5) \\
38.9(6)\end{array}$ \\
\hline 33. 4,5,6,7-Tetranitrobenzimidazolone & $5.0 \times 10^{6}(102)^{\mathrm{f}}$ & $10^{\mathrm{f}}$ & $(-0.199)$ & 220 & $31.5(4,7), 54.2(5,6)$ \\
\hline $\begin{array}{l}\text { 34. 2,4,6-Trinitrophenyl-1,3-bis- }(N \text {-ni- } \\
\text { traminoethylnitrate) (dipentryl) }\end{array}$ & $6.6 \times 10^{5}(16.7)$ & 95 & $(-0.189)$ & 366 & $\begin{array}{l}55.2(2), 45.9(4) \\
41.3(6)\end{array}$ \\
\hline $\begin{array}{l}\text { 35. 2,4-Dinitrophenyl- } N \text {-methylni- } \\
\text { tramine }\end{array}$ & $5.2 \times 10^{4}(4.4)^{\mathrm{c}}$ & 60 & $(-0.176)$ & 199 & $27.5(2)$ \\
\hline $\begin{array}{l}\text { 36. 2,4,6-Trinitrophenyl- } N \text {-methylni- } \\
\text { tramine (tetryl) }\end{array}$ & $2.6 \times 10^{5}(73.0)^{c}$ & 40 & $(-0.156)$ & 217 & $33.7(2), 36.6(6)$ \\
\hline $\begin{array}{l}\text { 37. 2,4,6-Trinitrophenyl- } N \text {-nitramino- } \\
\text { ethylnitrate (pentryl) }\end{array}$ & $5.7 \times 10^{5}(75.0)^{\mathrm{c}}$ & & $(-0.136)$ & 264 & $54.9(2), 25.9(6)$ \\
\hline 38. 1,3,5,8-Tetranitrocarbazole (TNC) & $5.0 \times 10^{5}(50.5)$ & 3.1 & $(-0.116)$ & 270 & \\
\hline
\end{tabular}

${ }^{a}$ The values of $k_{\text {cat }}$ are given in parentheses. The standard error of determination, $\pm 10 \%$; brom Šarlauskas et al., 2004a; ' from Čènas $e$ t al.,

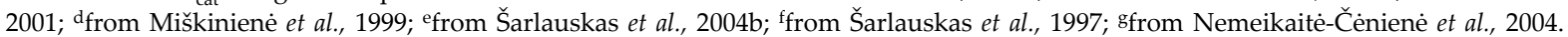


$=0.454$, data not shown). Because the directly determined $E_{7}^{1}$ values are unavailable for a large number of efficient NQO1 substrates (Table 1), we also used their $E_{7}^{1}$ values calculated from the data of their single-electron enzymatic reduction $\left(\mathrm{E}_{7 \text { (calc.)' }}^{1}\right.$ Table 1$)$ (Šarlauskas et al., 2006). This method gives realistic $\mathrm{E}^{1}{ }_{7 \text { (calc.) }}$ values for nitroaromatic compounds, which differ from the directly measured $\mathrm{E}_{7}^{1}$ values by not more than $35 \mathrm{mV}$ (Table 1). The expanded range of reduction potentials of compounds, $-0.50573--0.11$ $\mathrm{V}$, enabled us to obtain a more pronounced relationship between the $\mathrm{E}_{7 \text { (calc.) }}^{1}$ of the nitroaromatics and their $\log k_{\text {cat }} / K_{\mathrm{m}}\left(r^{2}=0.709\right.$, Fig. 2B $)$, or $\log k_{\text {cat }}\left(r^{2}=\right.$ 0.650 , data not shown). However, the significant data uncertainty shows that the reactivity of nitroaromatics is strongly influenced by other factors. Because the $k_{\text {cat }} / K_{\mathrm{m}}$ is the specificity constant of an enzyme (Koshland, 2002, and references therein), summarizing the effects of the productive or nonproductive substrate binding, and the possible variations in the catalytic power, further analysis of NQO1 reactivity was performed using this parameter. In catalysis of NQO1, the $k_{\mathrm{cat}} / K_{\mathrm{m}}$ of oxidants are equal to their bimolecular rate constants of reoxidation of reduced enzyme, obtained in stopped-flow experiments (Tedeschi et al., 1995).

Subsequently, we performed a multiparameter analysis of the reactivity of nitroaromatics using the following parameters: i) their Van der Waals volume (VdWvol) (Table 1). We have previously shown that using a series of quinones with similar $\mathrm{E}_{7}^{1}$ values, the reactivity of NQO1 started to decrease as the VdWvol of the quinones exceeded $200 \AA^{3}$, i.e., for tricyclic quinones, and benzo- or naphthoquinones with bulky substituents (Anusevičius et al., 2002); ii) the competitive inhibition constants $\left(K_{\mathrm{i}}\right)$ of nitroaromatics, i.e., their binding efficiency. Nitroaromatic compounds inhibit $\mathrm{NAD}(\mathrm{P}) \mathrm{H}$ :quinone reductase reactions of NQO1, acting as inhibitors competitive to $\mathrm{NAD}(\mathrm{P}) \mathrm{H}$ (Šarlauskas et al., 1997, and references therein). This is due to the low efficiency of nitroaromatics as NQO1 substrates, and their binding at the $\mathrm{NAD}(\mathrm{P}) \mathrm{H}$-binding site of the oxidized enzyme form. We have determined the $K_{\mathrm{i}}$ values for 22 out of the 38 compounds studied in this work (Table 1); and iii) torsion angle between the nitrogroup(s) and the aromatic ring, obtained by means of quantum mechanical calculations (Table 1). Previously we have suggested that the sterical crowding of nitrogroups in polynitrobenzimidazoles increasing their torsion angle may facilitate their reduction by NQO1, e.g., by decreasing the distance of hydride transfer (Šarlauskas et al., 1997).

The introduction of VdWvol as a second variable improved the regression $\left(r^{2}=0.753\right)$ :

$\log k_{\mathrm{cat}} / K_{\mathrm{m}}=(5.2252 \pm 0.7341)+(9.8722 \pm 1.3233)$

$\mathrm{E}_{7 \text { (calc.) }}^{1}+(0.0055 \pm 0.0022) \mathrm{VdW}$ vol.
The use of $\log K_{\mathrm{i}}$ also improved the relationship $\left(r^{2}=0.774\right.$ vs. $r^{2}=0.726$ for the linear dependence of $\log k_{\text {cat }} / K_{\mathrm{m}}$ on $\mathrm{E}_{7 \text { (calc.) }}^{1}$ for the 22 examined compounds):

$\log k_{\text {cat }} / K_{\mathrm{m}}=(7.4752 \pm 0.5417)+(9.6183 \pm 2.0192)$ $\mathrm{E}_{7 \text { (calc.) }}^{1}-(0.6367 \pm 0.3275) \log K_{\mathrm{i}}$.

At present, we are unable to relate the efficiency of binding of nitroaromatics, i.e., the $K_{\mathrm{i}^{\prime}}$ with their structural peculiarities. However, there exists a scattered parabolic dependence $\left(r^{2}=0.434\right)$ of the $\log K_{\mathrm{i}}$ of compounds on their VdWvol, showing a certain enzyme preference for compounds with VdWvol $=250-300 \AA^{3}$ (Fig. 3). Thus, most probably, both Eqns. 1 and 2 reflect a positive relationship between the VdWvol of nitroaromatics, their binding efficiency, and their reactivity.

Alternatively, the introduction of the nitrogroup highest torsion angle as a second variable also improved the relationship $\left(r^{2}=0.802\right)$ :

$\log k_{\mathrm{cat}} / K_{\mathrm{m}}=(5.7801 \pm 0.4189)+(9.8801 \pm 1.1035)$ $\mathrm{E}_{7 \text { (calc.) }}^{1}+(0.0219 \pm 0.0054)$ torsion angle.

Importantly, a combined use of the highest torsion angle and VdWvol or $\log K_{i}$ as additional variables did not improve the regressions:

$\log k_{\mathrm{cat}} / K_{\mathrm{m}}=(5.5003 \pm 0.6691)+(9.6435 \pm 1.1991)$

$\mathrm{E}_{7 \text { (calc.) }}^{1}+(0.0013 \pm 0.0024) \mathrm{VdWvol}+(0.0198 \pm 0.0070)$

torsion angle $\left(r^{2}=0.804\right)$,

and

$\log k_{\text {cat }} / K_{\mathrm{m}}=(6.7732 \pm 0.7453)+(9.6955 \pm 2.01056)$ $\mathrm{E}_{7 \text { (calc.) }}^{1}-(0.5043 \pm 0.3805) \log K_{\mathrm{i}}+(0.0182 \pm 0.0081)$ torsion angle $\left(r^{2}=0.793\right)$

Eqns. 4 and 5 show that an increase in the torsion angle definitely enhances the reactivity, whereas the role of $\log K_{\mathrm{i}}$ is less certain, and the role of VdWvol is definitely uncertain. In all the cases, the introduction of $(\mathrm{VdWvol})^{2}$ as an additional variable did not improve the regression (not shown).

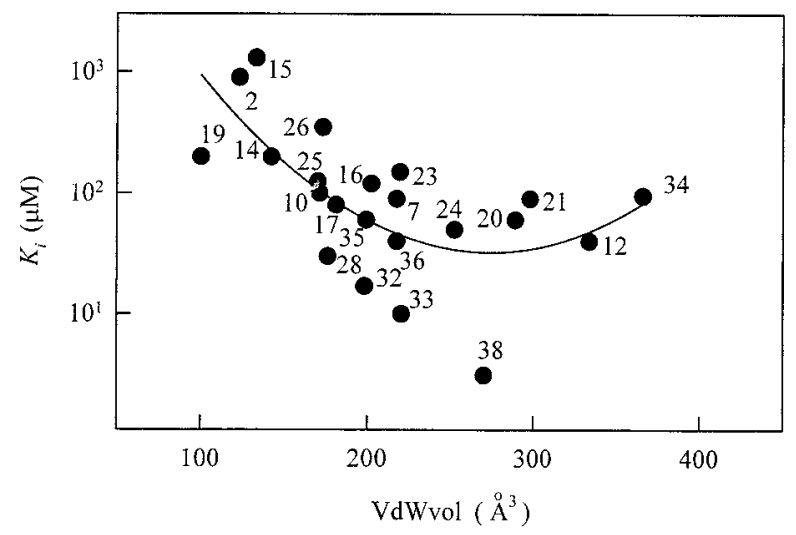

Figure 3. Dependence of the competitive inhibition constants $\left(K_{\mathrm{i}}\right)$ of nitroaromatic compounds on their Van der Waals volume (VdWvol).

The numbering of compounds is taken from Table 1. 
Table 2. Reduction rate constants of quinones and nitroaromatic compounds by NQO1, and their activation enthalpies $\left(\Delta \mathbf{H}^{\neq}\right)$and entropies $\left(\Delta S^{\neq}\right)$.

The reactions were studied in the absence of NQO1 activators, in order to avoid the possible effects of temperature on the enzyme interaction with detergent and albumin.

\begin{tabular}{lllll}
\hline No. Compound & $k_{\mathrm{cat}}\left(\mathrm{s}^{-1}\right)$ & $k_{\mathrm{cat}} / K_{\mathrm{m}}\left(\mathrm{M}^{-1} \mathrm{~s}^{-1}\right)$ & $\Delta \mathrm{H}^{\neq}\left(\mathrm{kJ} \mathrm{mol}^{-1}\right)$ & $\Delta \mathrm{S}^{\neq}\left(\mathrm{J} \mathrm{mol}^{-1} \mathrm{~K}^{-1}\right)$ \\
\hline 1. Tetramethyl-1,4-benzoquinone $^{\mathrm{a}}$ & $1000 \pm 90$ & $6.7 \pm 0.8 \times 10^{7}$ & $4.44 \pm 1.05$ & $-76.09 \pm 3.44$ \\
2. 2-Hydroxy-1,4-naphthoquinone & $232 \pm 25$ & $5.9 \pm 0.5 \times 10^{6}$ & $10.10 \pm 3.35$ & $-84.43 \pm 8.30$ \\
3. 5-(Aziridin-1-yl)-2,4-dinitro-benzoic acid ethyl ester & $0.67 \pm 0.08$ & $1.6 \pm 0.07 \times 10^{4}$ & $39.72 \pm 2.59$ & $-31.33 \pm 1.61$ \\
4. 2,4,6-Trinitrophenyl- $N$-methyl-nitramine (tetryl) & $20.5 \pm 1.5$ & $1.5 \pm 0.1 \times 10^{5}$ & $39.48 \pm 2.95$ & $-13.39 \pm 0.96$ \\
5. 1,4-Dinitrobenzene & $0.59 \pm 0.08$ & $2.4 \pm 0.1 \times 10^{3}$ & $50.58 \pm 10.31$ & $-8.81 \pm 2.25$ \\
\hline
\end{tabular}

aFrom Anusevičius et al., 2002.

Previously we have found that the reduction of 'bulky' quinones with VdWvol > $200 \AA^{3}$ by NQO1 is characterized by more positive entropies of activation $\left(\Delta S^{\neq}\right)$as compared to quinones with $\mathrm{VdWvol}$ $\leq 200 \AA^{3}$ (Anusevičius et al., 2002). This is probably related to a less favourable orientation of 'bulky' quinones in the enzyme active center and less efficient electronic coupling with the isoalloxazine ring of reduced FAD. Thus, we studied the temperature dependence of nitroreductase reactions. The data of Table 2 show that the nitroreductase reactions of NQO1 are characterized by a more positive $\Delta S^{\neq}$as compared to the reduction of the quinones with $\mathrm{Vd}$ Wvol $<200 \AA^{3}$, tetramethyl-1,4-benzoquinone and 2hydroxy-1,4-naphthoquinone.

Finally, we tried to characterize the binding of nitroaromatic compounds to the reduced state of NQO1, examining the effect of dicumarol on the kinetics of their reduction. It is universally accepted that dicumarol acts as an inhibitor of NQO1 competitive to $\mathrm{NAD}(\mathrm{P}) \mathrm{H}$, which binds at the binding domain of the dihydronicotinamide ring of $\mathrm{NAD}(\mathrm{P}) \mathrm{H}$ in the vicinity of the isoalloxazine ring of FAD (Prochaska, 1988; Chen et al., 1999, and references therein). In this case, the efficient inhibition by dicumarol $\left(K_{\mathrm{i}}=10 \mathrm{nM}\right.$ (Anusevičius et al., 2002)) reflects its binding to the oxidized state of NQO1. The binding of dicumarol to the reduced state of NQO1 did not receive much attention. Because dicumarol shifts the standard redox potential of NQO1 from -0.159
$\mathrm{V}$ to $-0.234 \mathrm{~V}$ (Tedeschi et al., 1995), it should bind to the reduced state of NQO1 with a much lower affinity than to the oxidized state. Thus, the effects of dicumarol on the $k_{\text {cat }} / K_{\mathrm{m}}$ of oxidants which interact with the reduced state of NQO1 may be observed only at high dicumarol concentrations, far exceeding its competitive $K_{\mathrm{i}}$ towards $\mathrm{NAD}(\mathrm{P}) \mathrm{H}$. The data of Fig. 4A shows that the micromolar concentrations of dicumarol decrease the maximal rate of reduction of 4,5,6,7-tetranitrobenzimidazolone (compound 33), i.e., increase the intercepts of Lineweaver-Burk plots with the $y$ axis, and decrease its $k_{\text {cat }} / K_{\mathrm{m}}$, i.e., increase the slopes of the plots (Fig. 4A). The $K_{\mathrm{i}}$ determined according to the slopes, $0.5 \pm 0.07 \mu \mathrm{M}$, reflects the binding of dicumarol to the reduced enzyme form, and its competition with 4,5,6,7-tetranitrobenzimida-zolone, whereas the $K_{\mathrm{i}}$ determined according to the intercepts, $0.15 \pm 0.02 \mu \mathrm{M}$, reflects the binding of dicumarol to the oxidized form of NQO1 and its competition with the high concentration of NADPH, $200 \mu \mathrm{M}$. Analogously we examined the effects of dicumarol on the $k_{\text {cat }} / K_{\mathrm{m}}$ of a 'fast' quinone oxidant, 2-methyl-3-hydroxy-1,4-naphthoquinone, and the nitroaromatic compounds tetryl and 5-(aziridin-1yl)-2,4-dinitrobenzoic acid ethyl ester. The obtained Dixon plots are presented together in Fig. 4B. Because of the different $k_{\text {cat }} / K_{\mathrm{m}}$ of the oxidants, the data were normalized by plotting $\left(k_{\text {cat }} / K_{\mathrm{m}}\right)_{0} /\left(k_{\text {cat }} / K_{\mathrm{m}}\right)$ instead of $1 /\left(k_{\text {cat }} / K_{\mathrm{m}}\right)$, where $\left(k_{\text {cat }} / K_{\mathrm{m}}\right)_{0}$ is the reduction rate constant in the absence of dicumarol. The
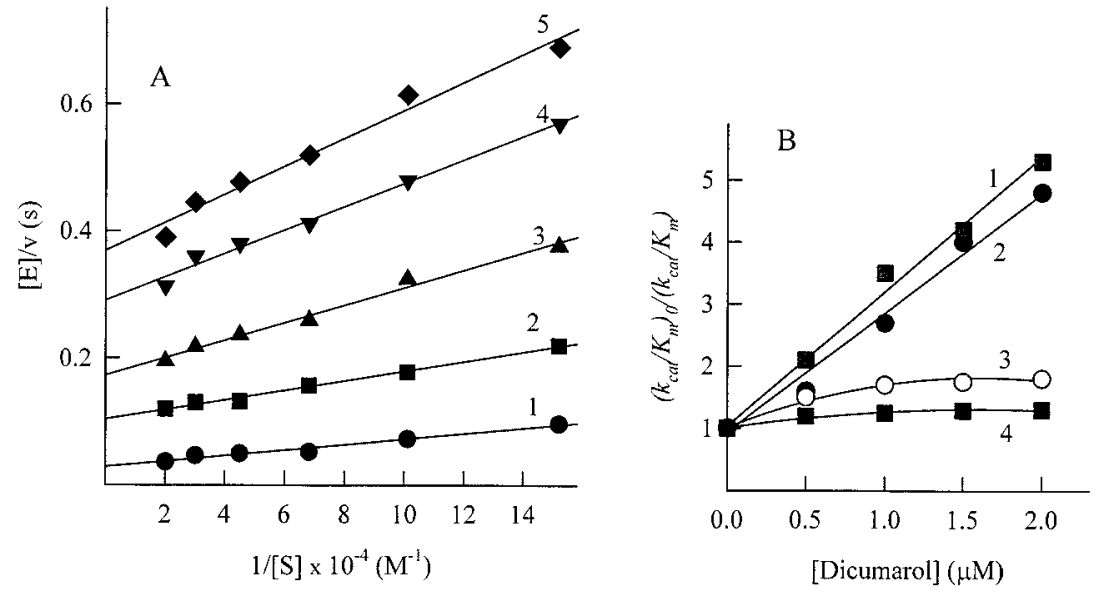

Figure 4. Inhibition of nitro- and quinone reductase reactions of NQO1 by dicumarol.

A. The rates of reduction of $4,5,6,7-$ tetranitrobenzimidazolone in the absence of dicumarol (1), and in the presence of $0.5 \mu \mathrm{M}$ (2), $1.0 \mu \mathrm{M}$ (3), $1.5 \mu \mathrm{M}(4)$, and $2.0 \mu \mathrm{M}$ dicumarol (5). B. The influence of dicumarol on $k_{\text {cat }} / K_{\mathrm{m}}$ of 2-methyl-3-hydroxy1,4-naphthoquinone (1), 4,5,6,7-tetranitrobenzimidazolone (2), tetryl (3), and 5-(aziridin-1-yl)-2,4-dinitrobenzoic acid ethyl ester (4). The reactions was performed in the absence of activators of NQO1. 
data of Fig. 4B show that dicumarol is a linear inhibitor with respect to 2-methyl-3-hydroxy-1,4-naphthoquinone and 4,5,6,7-tetranitrobenzimidazolone. In contrast, it behaves as a nonlinear inhibitor with respect to 5-(aziridin-1-yl)-2,4-dinitrobenzoic acid ethyl ester and tetryl, decreasing their $k_{\text {cat }} / K_{\mathrm{m}}$ by the limiting factors of 1.2 and 1.7, respectively (Fig. 4B).

\section{DISCUSSION}

Our work discloses several important features of nitroreductase reactions of NQO1, which were not evident before. The use of a large number of compounds with a broad range of $E_{7 \text { (calc.) }}^{1}$ enabled us to demonstrate that an increase in the electron accepting potency of nitroaromatics increases their reactivity (Fig. 2B), although the reactivity is also strongly influenced by the structural features of the compounds. All the quantitative structure-activity relationships obtained (Eqns. 1-5) show the coefficient $\Delta \log k_{\text {cat }} / K_{\mathrm{m}} / \Delta \mathrm{E}_{7 \text { (calc.) }}^{1} \sim 10 \mathrm{~V}^{-1}$. Similar coefficients are characteristic of the single-electron reduction of nitroaromatic compounds by flavoenzyme electrontransferases, which follow an outer-sphere electron-transfer model (Orna \& Mason, 1989; Čènas et al., 2001), and of the two-electron reduction of nitroaromatics by E. cloacae nitroreductase (Nivinskas et al., 2001). Although $\mathrm{E}_{7}^{1}$ or $\mathrm{E}_{7 \text { (calc.) }}^{1}$ may parallel the energetics of two-electron (hydride) transfer, this coefficient may also point to the multistep $\left(\mathrm{e}^{-}, \mathrm{H}^{+}, \mathrm{e}^{-}\right)$ hydride transfer in nitroreduction, with a rate-limiting first electron transfer.

It seems that the increased affinity of nitroaromatics for NQO1, i.e., their lower $K_{\mathrm{i}}$ may enhance their reactivity (Eqns. 2 and 5). However, at present we cannot precisely identify the structural requirements for the efficient binding of nitroaromatic compounds. Besides, an efficient compound binding does not imply that the compound will bind with the productive orientation. On the other hand, we may unequivocally conclude that an increase in the torsion angle of nitrogroup(s) (Table 1) enhances the reduction of nitroaromatic compounds by NQO1 (Eqns. 4 and 5). This finding is in line with the observed specific reduction of the 4-nitro group of CB-1954 by NQO1 (Knox \& Chen, 2004), which possesses a higher torsion angle than 2-nitro group (Table 1). It may also serve as an indirect evidence that the nitroreduction occurs as the direct electron (hydride) transfer to the nitrogroup, but not to the aromatic ring.

However, the above factors may just partly explain the substrate specificity of nitroreductase reactions of NQO1, because the obtained multiparameter regressions are relatively uncertain. Therefore, we should consider possible differences in the mode of the binding of nitroaromatic compounds in the active center of NQO1. Two available computer modeling studies (Chen et al., 1999; Skelly et al., 1999) propose that CB-1954 should form a $\pi-\pi$ complex with the isoalloxazine ring of FAD by displacement of Tyr-128', and interact with Tyr-126', His-161, and Phe-106. In this case, CB-1954 should occupy the binding site of quinones and dicumarol (Chen et al., 1999; Bianchet et al., 2004). However, our data do not agree with this model. First, the more positive $\Delta S^{\neq}$of nitroaromatic compounds as compared to quinones (Table 2) point to a less efficient electronic coupling of nitroaromatics with reduced isoalloxazine. This may explain their lower reactivity as compared to quinones. Second, dicumarol acts as an incomplete inhibitor towards an analogue of CB-1954, 5-(aziridin-1-yl)-2,4-dinitrobenzoic acid ethyl ester, and another nitroaromatic compound, tetryl (Fig. 4B). This means that these compounds and dicumarol bind at separate or weakly overlapping sites at the reduced form of NQO1. Previously, we have found that dicumarol and slowly reacting quinones with $\mathrm{VdWvol}>200 \AA^{3}$ bind to oxidized NQO1 at separate regions of the enzyme (Anusevičius et al., 2002). On the other hand, the linear character of inhibition of dicumarol with respect to 2-methyl-3-hydroxy-1,4-naphthoquinone (Fig. 4B) shows that both compounds bind at the same site, which is in agreement with the X-ray and computer modeling data (Chen et al., 1999; Bianchet et al., 2004). Importantly, the linear inhibition by dicumarol of 4,5,6,7-tetranitrobenzimidazolone reduction (Fig. 4B) also implies that this compound binds at or close to the dicumarol/quinone binding site. Probably, this is the reason of a much higher than expected reactivity of 4,5,6,7-tetranitrobenzimidazolone (Fig. 2B).

In conclusion, we demonstrated that an increased electron accepting potency and an increased nitrogroup torsion angle may enhance the reduction of nitroaromatic compounds by NQO1. Another important but poorly understood factor enhancing the reactivity of nitroaromatics is their ability ot bind at the dicumarol/quinone binding site. Our work provides some guidelines for computer modeling studies, showing the possibility of binding of nitroaromatic compounds at different sites in the active center of NQO1, as well as for the synthesis of new efficient nitroaromatic substrates for NQO1.

\section{Acknowledgements}

This study was supported in part by the Lithuanian State Science and Studies Foundation.

\section{REFERENCES}

Agrawal JP, Surve RN, Mehilal, Sonawase SH (2000) Some aromatic nitrate esters: synthesis, structural aspects, 
thermal and explosive properties. J Hazard Mater 77A: 11-31.

Anusevičius Ž, Šarlauskas J, Čènas N (2002) Two-electron reduction of quinones by rat liver $\mathrm{NAD}(\mathrm{P}) \mathrm{H}$ :quinone oxidoreductase: quantitative structure-activity relationships. Arch Biochem Biophys 404: 254-262.

Arlt VM, Stiborova M, Henderson CJ, Osborne MR, Bieler CA, Frei E, Martinek V, Sopko B, Wolf CR, Schmeiser $\mathrm{HH}$, Phillips DH (2005) Environmental pollutant and potent mutagen 3-nitrobenzanthrone forms DNA adducts after reduction by $\mathrm{NAD}(\mathrm{P}) \mathrm{H}$ :quinone oxidoreductase and conjugation by acetyltransferases and sulfotransferases in human hepatic cytosol. Cancer Res 65: 2644-2652.

Bianchet MA, Faig M, Amzel LM (2004) Structure and mechanism of $\mathrm{NAD}[\mathrm{P}] \mathrm{H}$ :quinone acceptor oxidoreductases. Methods Enzymol 382B: 144-174.

Čènas N, Nemeikaitè-Čènienè A, Sergedienė E, Nivinskas H, Anusevičius Ž, Šarlauskas J (2001) Quantitative structure-activity relationships in enzymatic single-electron reduction of nitroaromatic explosives: implications for their cytotoxicity. Biochim Biophys Acta 1528: 31-38.

Čènas N, Anusevičius Ž, Nivinskas H, Misevičienè L, Šarlauskas, J (2004) Structure-activity relationships in two-electron reduction of quinones. Methods Enzymol 382B: $258-277$.

Chen S, Wu K, Zhang D, Sherman M, Knox R, Yang CS (1999) Molecular characterization of binding of substrates and inhibitors to DT-diaphorase: combined approach involving site-directed mutagenesis, inhibitorbinding analysis, and computer modeling. Mol Pharmacol 58: 272-278.

DiFrancesco AM, Ward TH, Butler J (2004) Diaziridinylbenzoquinones. Methods Enzymol 382B: 174-193.

Knox RJ, Chen S (2004) Quinone reductase-mediated nitroreduction: clinical applications. Methods Enzymol 382B: 194-221.

Koshland DE Jr (2002) The application and usefulness of the ratio $k_{\text {cat }} / K_{\mathrm{m}}$. Bioorg Chem 30: 211-213.

Mehilal, Sikder AK, Sinha RK, Gandhe BR (2003) Cost-effective synthesis of 5,7-diamino-4,6-dinitrobenzofuroxan (CL-14) and its evaluation in plastic bonded explosives. J Hazard Materials 102A: 137-145.

Miškinienė V, Sergedienė E, Nemeikaitė A, Segura-Aguilar J, Čènas N (1999) Role of redox cycling and activation by DT-diaphorase in the cytotoxicity of 5-(aziridin-1yl)-2,4-dinitro-benzamide (CB-1954) and its analogs. Cancer Lett 146: 217-222.

Nemeikaitè-Čènienè A, Šarlauskas J, Misevičienė L, Anusevičius Ž, Marozienė A, Čènas N (2004) Enzymatic redox reactions of the explosive 4,6-dinitrobenzofuroxan (DNBF): implications for its toxic action. Acta Biochim Polon 51: 1081-1086.

Nivinskas H, Koder RL, Anusevičius Ž, Šarlauskas J, Miller A-F, Čènas N (2001) Quantitative structure-activity relationships in two-electron reduction of nitroaromatic compounds by Enterobacter cloacae NAD(P)H:nitroreductase. Arch Biochem Biophys 385: 170-178.

Orna VM, Mason RP (1989) Correlation of kinetic parameters of nitroreductase enzymes with redox properties of nitroaromatic compounds. J Biol Chem 264: 1237912384.

Prochaska HJ (1988) Purification and crystallization of rat liver NAD(P)H:(quinone-acceptor) oxidoreductase by cibacron blue affinity chromatography: identification of a new and potent inhibitor. Arch Biochem Biophys 267: 529-538.

Race PR, Lovering AL, Green RM, Ossor A, White SA, Searle PF, Wrighton CJ, Hyde EI (2005) Structural and mechanistic studies of Escherichia coli nitroreductase with the antibiotic nitrofurazone. Reversed binding orientations in different redox states of the enzyme. J Biol Chem 280: 13256-13264.

Riefler RG, Smets BF (2000) Enzymatic reduction of 2,4,6trinitrotoluene and related nitroarenes: kinetics linked to one-electron reduction potentials. Environ Sci Technol 34: 3900-3906.

Ross D, Kepa JK, Winski SL, Beall HD, Anwar A, Siegel D (2000) NAD(P)H:quinone oxidoreductase 1 (NQO1): chemoprotection, bioactivation, gene regulation and genetic polymorphisms. Chem-Biol Interact 129: 77-97.

Šarlauskas J, Dičkancaitė E, Nemeikaitė A, Anusevičius Ž, Nivinskas H, Segura-Aguilar J, Čènas N (1997) Nitrobenzimidazoles as substrates for DT-diaphorase and redox cycling compounds: their enzymatic reactions and cytotoxicity. Arch Biochem Biophys 346: 219-229.

Šarlauskas J, Nemeikaitè-Čènienè A, Anusevičius Ž, Misevičienė L, Martinez-Julvez M, Medina M, GomezMoreno C, Čenas N (2004a) Flavoenzyme-catalyzed redox cycling of hydroxylamino- and amino metabolites of 2,4,6-trinitrotoluene: implications for their cytotoxicity. Arch Biochem Biophys 425: 184-192.

Šarlauskas J, Nemeikaitè-Čènienė A, Anusevičius Ž, Misevičienė L, Marozienė A, Markevičius A, Čènas N (2004b) Enzymatic redox properties of novel nitrotriazole explosives. Implications for their cytotoxicity. $Z$ Naturforsch 59c: 399-404.

Šarlauskas J, Nivinskas H, Anusevičius Ž, Misevičienè L, Marozienė A, Čènas N (2006) Estimation of single-electron reduction potentials $\left(\mathrm{E}_{7}^{1}\right)$ of nitroaromatic compounds according to the kinetics of their single-electron reduction by flavoenzymes. Chemija (Vilnius) 17: 31-37.

Skelly JV, Sanderson MR, Suter DA, Bauman U, Read MA, Gregory DSJ, Bennett M, Hobbs SM, Neidle S (1999) Crystal structure of human DT-diaphorase: a model for interaction with the cytotoxic prodrug 5-(aziridin1-yl)-2,4-dinitrobenzamide (CB1954) J Med Chem 42: 4325-4330.

Tedeschi G, Chen S, Massey V (1995) DT-diaphorase. Redox potential, steady-state, and rapid reaction studies. J Biol Chem 270: 1198-1204.

Wardman P (1989) Reduction potentials of one-electron couples involving free radicals in aqueous solutions. $J$ Phys Chem Ref Data 18: 1637-1755.

Zuman P, Fijalek Z, Dumanovic D, Suznjevic D (1992) Polarographic and electrochemical studies of some aromatic and heterocyclic nitro-compounds. 1. General mechanistic aspects. Electroanalysis 4: 783-794. 